\title{
セラミックス資材による水質浄化に関する研究
}

\author{
福元康文 ${ }^{1} \cdot$ 西村安代 $^{2} \cdot$ 島崎一彦 $^{1}$ \\ ${ }^{1}$ 高知大学農学部 783-8502 高知県南国市物部乙 200 \\ ${ }^{2}$ 川合肥料株式会社４38-0068 静岡県磐田市前野 2226
}

\section{Studies on the Purification of Water by the Ceramics Materials}

\author{
Yasufumi Fukumoto ${ }^{1}$, Yasuyo Nishimura ${ }^{2}$ and Kazuhiko ShIMASAKI ${ }^{1}$ \\ ${ }^{1}$ Faculty of Agriculture, Kochi University, Monobe, Nankoku, Kochi, 783-8502 Japan \\ ${ }^{2}$ Kawai Hiryo Co. Ltd., Maeno, Iwata, Shizuoka, 438-0068 Japan
}

\begin{abstract}
Effects of ceramics in water purification were evaluated. All ceramics materials tested suppressed the growth of algae. This effect was particularly strong with the magnesium oxide -added ceramics and with FIB-25. $\mathrm{pH}$ was higher in the fields treated with ceramics containing magnesium oxide. EC tended to be lower in the fields treated with ceramics containing magnesium oxide and in the FIB-25 treated fields. The addition of ceramics containing magnesium oxide to soil resulted in markedly improved water quality through suppression of algae growth and adsorption of phosphorus. This ceramics is promising as a means of improving water quality.
\end{abstract}

Keywords : algae, ceramics, magnesium, oxide, purification, water

\section{緒言}

近年，工場排水や家庭排水による河川湖沼の水質悪化 が大きな社会問題となっている1). 栽培面積が急速に増 加している養液栽培においても, 養液の廃液が水質環境 污染の一要因とも言われている. 環境基準の変更ととも に, 環境破壊要因に対する規制の強化が求められ，早急 な水質浄化対策が望まれている.

河川・湖沼が富栄養化すると水面に藻の発生が認めら れ，水質悪化が進んでいる証拠とも言われている。また 養液栽培の養液漕や灌水チューブ内に認められる藻の発 生は, 作物栽培に用いる灌水チューブ内エミッターの目 詰まりの要因ともなり，その対策が望まれている.

河川・湖沼や養液槽における水質浄化に対する試みは

2002 年 12 月 6 日受付

2003 年 4 月 10 日受理

Corresponding author: Yasufumi Fukumoto (yfuk@cc.kochi-u.ac.jp)
様々であり，次に述べるような方法である程度成果があ げられている。例えば，湖底に堆積した污泥を直接機械 で搬出し，その污泥の再利用を図る方法 ${ }^{2 \sim 4)}$, 湖沼を対 象とした植物の水上栽培により，窒素を主とする無機塩 類の吸収除去を行う方法 ${ }^{528)}$ ， あるいは化学的な窒素除 去技術 ${ }^{9}$ などである. また窒素とともに重要視されるリ ン酸の除去には, カニガラなどの利用による吸着除去が 試みられているが，効果は不安定 ${ }^{9}$ である.

セラミックスは, 藻の発生抑制, 水質劣悪化防止, 水 の活性化, 水の抗菌, 防臭効果, 吸湿作用など様々なこ とが言われてはいるが，これらに関する報告は，多孔質 による吸湿効果と, セピオライトのアンモニア臭の吸着 による防臭効果 ${ }^{10}$ 以外，ほとんど見られない.

そこでセラミックスに着目し，水質浄化作用について 検討を行った，各種化学的性質と形状の異なるセラミッ クス資材と, 酸化マグネシウムを混入したセラミックス を用い, 水質特にリン酸の吸着除去と藻の発生への影響 について検討を加え, 今後の水質浄化技術開発の一助と した. 


\section{材料および方法}

\section{実験 1 養液へのセラミックス資材添加効果}

2 月 4 日に発泡スチロール製の容器(内径 縌 $\times$ 横 $\times$ 深さ $=18.7 \mathrm{~cm} \times 66.1 \mathrm{~cm} \times 13.5 \mathrm{~cm})$ に Table 1 に示し た成分組成の養液 (EC 1. $322 \mathrm{dS} / \mathrm{m}, \mathrm{pH} 7.08)$ を各 10 リットル注入した。資材は $\mathrm{SiO}_{2}$ と $\mathrm{Al}_{2} \mathrm{O}_{3}$ を主成分とし たハイアルミナ系ゼオライト岩石を $2000^{\circ} \mathrm{C}$ の高温で溶 融し, 特殊反応を繰り返し反応させ，ポーラス部を多く したものを供試した．養液中にセラミックス SE7 (成形 の径 13〜 $15 \mathrm{~mm} ：$ A) と同材に酸化マグネシウム $(\mathrm{MgO})$ を $9.27 \%$ 混入した酸化マグネシウム入りセラミックス (成形の径 13〜 $15 \mathrm{~mm} ： \mathrm{~B}$ ) を各 $500 \mathrm{~g} /$ 区を添加する 2 処理区と無添加の対照区の合計 3 区を設けた. なお供試 した $\mathrm{A}, \mathrm{B}$ の表面積は $2,341 \mathrm{~cm}^{2} / \mathrm{L}$ ，見掛け気孔率は $35.4 \%$, 真比重は $3.01 \mathrm{~g} / \mathrm{cm}^{3}$, 空間堆積は $428 \mathrm{~cm}^{3} / \mathrm{L}$ であった. 容器には発泡スチロール製の蓋をし, 最低気 温を $10^{\circ} \mathrm{C}$ 以上, 最高気温を $25^{\circ} \mathrm{C}$ 以下に保った八ウス内 で地上 $1 \mathrm{~m}$ の高さの架台上に一定期間静置後, 養液中 のリン酸濃度と, $\mathrm{pH}$ ・ $\mathrm{EC}$ を 2 月 26 日(処理開始 22 日 目)と 3 月 19 日(同 43 日目)の 2 回調査した.リン酸濃 度の計測はバナドモリブデン酸法による比色検定を分光 光度計 (HITACHI Spectro Photometer Model 100-60) を用いて行った。 また pH は Horiba pH Meter F-12 で EC は Conductivity Meter Toa CM-11P で計測した.

実験 2 酸化マグネシウム入りセラミックスと各種 セラミックス資材の水質浄化効果の比較

供試した発泡スチロール製の容器と養液は実験 1 と同 様とし, 成分比と形状の異なる 6 種類のセラミックス資 材を用いて行った。処理は 2 月 27 日に無処理と養液量 $10 \mathrm{~L}$ 当たり実験 1 と同資材 $\mathrm{A}, \mathrm{B}$ を $1.0 \mathrm{~kg}(\mathrm{~A} 1, \mathrm{~B} 1)$ と
$2.9 \mathrm{~kg}(\mathrm{~A} 2, \mathrm{~B} 2)$, さらに成形の径 $7 \sim 8 \mathrm{~mm} \mathrm{SD7}(\mathrm{C})$, 未成形の径 $7 \sim 8 \mathrm{~mm} \mathrm{~B}(\mathrm{D})$, 塊状インゴットの FIB-25 (E), 成形の径 7 ～ $8 \mathrm{~mm} \mathrm{SBW}(\mathrm{F})$ を $2.9 \mathrm{~kg}$ それぞれ養 液中に添加し, 実験 1 同様にハウス内に静置した。なお 成形はカットした資材を球状に磨きをかけ，未成形は カットしたままの資材である。 3 月 21 日に養液中のリ ン酸濃度, $\mathrm{pH}$ と $\mathrm{EC}$ を前実験同様に測定した。また藻 の発生を調査するためにクロロフィルの極大吸収波長の $645 \mathrm{~nm}$ と $663 \mathrm{~nm}$ の吸光度を分光光度計 (実験 1 参照)で 測定した.なお，実験 $1 ， 2$ の供試資材の化学組成は Table 2 に示した. またEの真比重は $3.65 \mathrm{~g} / \mathrm{cm}^{3}$ で, 気孔率と表面積も他の資材より高かった。

なお, サンプル液採取はガラス棒で約 10 分間覺汼し た後行ったが, 実験期間中の液の追加と攪汼は行わな かった。 また実験 1,2 とも 1 処理区 5 反覆で行った.

\section{結果および考察}

\section{実 験 1}

養液中のリン酸濃度は, 処理開始 22 日後では B 区で 低下傾向が認められ，他の 2 処理区よりも約 $5 \mathrm{ppm}$ 低 く,さらに 43 日目では低下傾向が一層明瞭となった (Fig. 1).またA区でも 43 日目の調査で低下傾向が認 められ, 22 日目よりも $3.7 \mathrm{ppm}$ 減少した。

養液の 2 月 26 日と 3 月 19 日調査時における $\mathrm{pH}$ は, $\mathrm{B}$ 区が $7.45,7.42$ といずれも他の 2 処理区よりも有意 に高くなった (Table 3).

また ECは処理による変化がほとんど認められなかっ た.

\section{実 験 2}

無処理区では藻の発生が認められ, 緑化が著しく, 濁 度が進んでいたが，B2 区では藻の発生が著しく抑制さ

Table 1 Mineral composition in nutrient solution.

\begin{tabular}{cccccccccccc}
\hline \hline Mineral & $\mathrm{N}$ & $\mathrm{P}$ & $\mathrm{K}$ & $\mathrm{Ca}$ & $\mathrm{Mg}$ & $\mathrm{Fe}$ & $\mathrm{Cu}$ & $\mathrm{Zn}$ & $\mathrm{Mn}$ & $\mathrm{Mo}$ & $\mathrm{B}$ \\
\hline $\begin{array}{c}\text { Concentration } \\
(\mathrm{ppm})\end{array}$ & 117.5 & 60.0 & 204.8 & 86.3 & 30.0 & 2.775 & 0.025 & 0.065 & 1.25 & 0.026 & 1.25 \\
\hline
\end{tabular}

Table 2 The chemical composition in ceramics materials. (\%)

\begin{tabular}{|c|c|c|c|c|c|c|c|c|c|c|c|c|c|c|}
\hline Material & & $\mathrm{SiO}_{2}$ & $\mathrm{Al}_{2} \mathrm{O}_{3}$ & MgO & $\mathrm{P}_{2} \mathrm{O}_{5}$ & $\mathrm{~K}_{2} \mathrm{O}$ & $\mathrm{CaO}$ & $\mathrm{Fe}_{2} \mathrm{O}_{3}$ & $\mathrm{MnO}$ & $\mathrm{Na}_{2} \mathrm{O}$ & $\mathrm{TiO}_{2}$ & $\mathrm{Cd}$ & $\mathrm{Pb}$ & Other \\
\hline Ceramic SE & : A & 45.90 & 43.48 & 0.10 & tr. & 1.59 & 0.74 & 4.53 & tr. & 1.41 & 2.00 & tr. & tr. & 0.25 \\
\hline $\begin{array}{l}\text { Ceramic including } \\
\text { magnesium oxide }\end{array}$ & $: \mathrm{B}$ & 41.69 & 39.49 & 9.27 & 0.04 & 1. 44 & 0.67 & 4. 11 & 0.05 & 1. 28 & 1. 82 & $\operatorname{tr}$. & tr. & 0.14 \\
\hline Ceramic SD7 & $: \mathrm{C}$ & 55.30 & 36.80 & 0.10 & $\operatorname{tr}$. & 2.56 & 0.62 & 1.24 & tr. & 1.86 & 1. 48 & $\operatorname{tr}$. & $\operatorname{tr}$ & 0.04 \\
\hline Ceramic B & $: D$ & 33.00 & 48.80 & 0.07 & tr. & tr. & 1. 50 & 10.60 & tr. & tr. & 4. 20 & tr. & $\operatorname{tr}$. & 1.83 \\
\hline FIB-25 & $: \mathrm{E}$ & 18.63 & 75.29 & 0.29 & 0.02 & 0.27 & 0.36 & 2.97 & 0.03 & 0.05 & 2. 09 & $\operatorname{tr}$. & tr. & 0.00 \\
\hline Ceramic SBW & $: \mathrm{F}$ & 55.10 & 35.00 & 0.09 & tr. & 2.71 & 0.59 & 0.74 & tr. & 1.33 & 1.15 & tr. & tr. & 3.29 \\
\hline
\end{tabular}




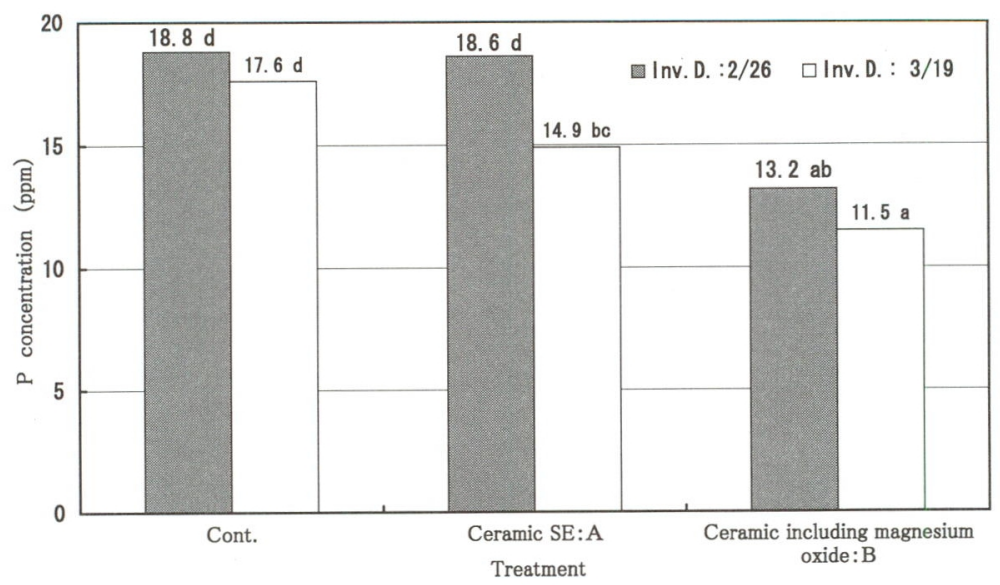

Fig. 1 The effects of ceramics materials addition on the phosphorus concentration in nutrient solution (Exp. 1).

Different letters are significantly different at $\mathrm{p}<0.05$ according to Duncan's new multiple range test.

Table 3 The effects of ceramics materials addition on the $\mathrm{pH}$ and $\mathrm{EC}$ in nutrient solution.

\begin{tabular}{lccc}
\hline \hline \multirow{2}{*}{ Treatment } & \multicolumn{2}{c}{$\mathrm{pH}$} & \multirow{2}{*}{$\mathrm{EC}^{\mathrm{y}}$} \\
\cline { 2 - 3 } & $2 / 26$ & $3 / 19$ & $(\mathrm{dS} / \mathrm{m})$ \\
\hline Cont. & $7.09 \mathrm{a}^{\mathrm{z}}$ & $7.04 \mathrm{a}$ & $1.149 \mathrm{a}$ \\
Ceramic SE : A & $7.09 \mathrm{a}$ & $6.90 \mathrm{a}$ & $1.144 \mathrm{a}$ \\
Ceramic including & $7.45 \mathrm{~b}$ & $7.42 \mathrm{~b}$ & $1.143 \mathrm{a}$ \\
magnesium oxide : B & & & \\
\hline
\end{tabular}

${ }^{z}$ Means within each column followed by different letters are significantly different at $\mathrm{p}<0.05$ according to Duncan's new multiple range test.

${ }^{\mathrm{y}}$ The investigation day month/day : $3 / 19$
れており，透明度が高かった（Fig. 2)。

$645 \mathrm{~nm}$ と $663 \mathrm{~nm}$ の吸光度の平均值は, 藻の発生が最 も顕著であった無処理区で 30.5 と最大となり，セラ ミックス資材を添加した区ではいずれの区も無処理区の 半分以下と有意に低下した。中でも B2 区は 2.5 と最も 低くなった (Table 4).

養液中のリン酸濃度は, B2, B1区で顕著に減少し, $1.7 \mathrm{ppm}$ と $15.8 \mathrm{ppm}$ であった(Fig. 3). 一方, 吸光度 が $\mathrm{B}$ 区と同様に低かった $\mathrm{E}$ 区では $26.6 \mathrm{ppm}$ と低下が 認められなかった.

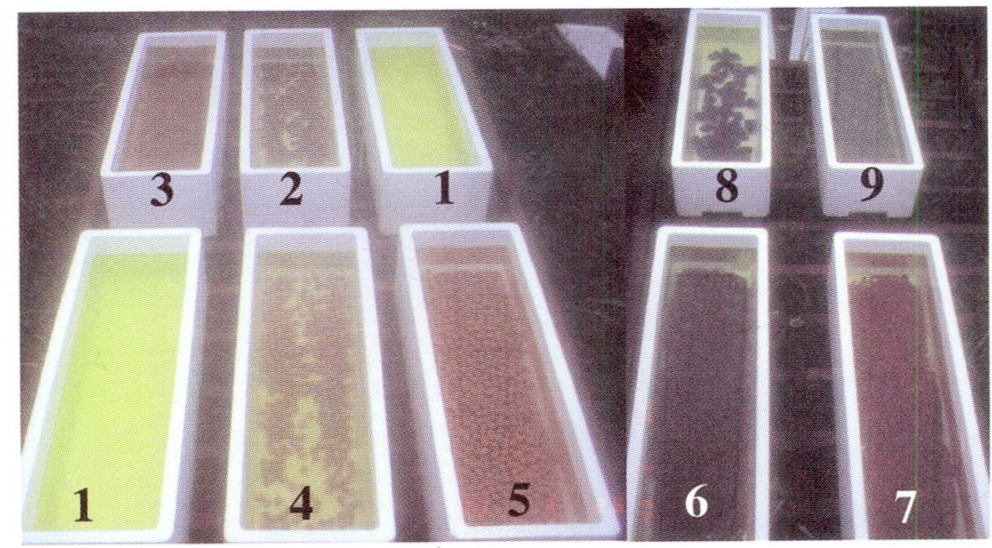

Fig. 2 The effects of ceramics materials addition in nutrient solution(Exp. 2).

1) Cont. 2) Ceramic SE $1.0 \mathrm{~kg}: \mathrm{A} 1$ 3) Ceramic SE $2.9 \mathrm{~kg}: \mathrm{A} 2$

4) Ceramic SE including magnesium oxide $1.0 \mathrm{~kg}: \mathrm{B} 1$

5) Ceramic SE including magnesium oxide $2.9 \mathrm{~kg}: \mathrm{B} 2$

6) Ceramic SD $72.9 \mathrm{~kg}:$ C 7) Ceramic B $2.9 \mathrm{~kg}: \mathrm{D}$

8) Ceramic FIB-25 $2.9 \mathrm{~kg}: \mathrm{E}$ 9) Ceramic SBW $2.9 \mathrm{~kg}: \mathrm{F}$ 
Table 4 The effects of ceramics materials addition on the absorvance, $\mathrm{pH}$ and EC nutrient solution.

\begin{tabular}{|c|c|c|c|c|c|c|c|}
\hline \multirow{2}{*}{\multicolumn{3}{|c|}{ Treatment }} & \multicolumn{3}{|c|}{ Absorvance } & \multirow{2}{*}{$\mathrm{pH}$} & \multirow{2}{*}{$\begin{array}{c}\mathrm{EC} \\
(\mathrm{dS} / \mathrm{m})\end{array}$} \\
\hline & & & $645 \mathrm{~nm}$ & $663 \mathrm{~nm}$ & Mean & & \\
\hline Cont. & & & $31 \mathrm{e}^{z}$ & $30 \mathrm{~d}$ & $30.5 \mathrm{e}$ & $7.54 \mathrm{~b}$ & $1.330 \mathrm{c}$ \\
\hline \multirow{2}{*}{ Ceramic SE } & : A1 & $1.0 \mathrm{~kg}$ & $9 \mathrm{~b}$ & $9 \mathrm{~b}$ & $9.0 \mathrm{bc}$ & 7. $41 \mathrm{~b}$ & 1. $312 \mathrm{bc}$ \\
\hline & $: \mathrm{A} 2$ & $2.9 \mathrm{~kg}$ & $16 \mathrm{~d}$ & $14 \mathrm{c}$ & $15.0 \mathrm{~d}$ & 7. $45 \mathrm{~b}$ & 1. $337 \mathrm{c}$ \\
\hline Ceramic including & $: \mathrm{B} 1$ & $1.0 \mathrm{~kg}$ & $10 \mathrm{~b}$ & $9 \mathrm{~b}$ & $9.5 \mathrm{bc}$ & $7.78 \mathrm{~b}$ & 1. $281 \mathrm{abc}$ \\
\hline magnesium oxide & $:$ B2 & $2.9 \mathrm{~kg}$ & $3 \mathrm{a}$ & $2 \mathrm{a}$ & $2.5 \mathrm{a}$ & $8.87 \mathrm{c}$ & 1. $251 \mathrm{a}$ \\
\hline Ceramic SD7 & $: \mathrm{C}$ & $2.9 \mathrm{~kg}$ & $15 \mathrm{~cd}$ & $7 \mathrm{~b}$ & $11.0 \mathrm{~cd}$ & 7. $37 \mathrm{a}$ & $1.388 \mathrm{~d}$ \\
\hline Ceramic B & :D & $2.9 \mathrm{~kg}$ & $11 \mathrm{bc}$ & $8 \mathrm{~b}$ & $9.5 \mathrm{bc}$ & $7.45 \mathrm{~b}$ & 1. $306 \mathrm{bc}$ \\
\hline FIB-25 & $: \mathrm{E}$ & $2.9 \mathrm{~kg}$ & $6 \mathrm{ab}$ & $6 \mathrm{ab}$ & $6.0 \mathrm{ab}$ & $7.42 \mathrm{~b}$ & 1. $280 \mathrm{ab}$ \\
\hline Ceramic SBW & $: F$ & $2.9 \mathrm{~kg}$ & $17 \mathrm{~d}$ & $14 \mathrm{c}$ & $15.5 \mathrm{~d}$ & $7.39 \mathrm{ab}$ & 1. $327 \mathrm{bc}$ \\
\hline
\end{tabular}

The investigation day month/day $: 3 / 21$

${ }^{2}$ Means within each column followed by different letters are significantly different at $\mathrm{p}<0.05$ according to Duncan's new multiple range test.

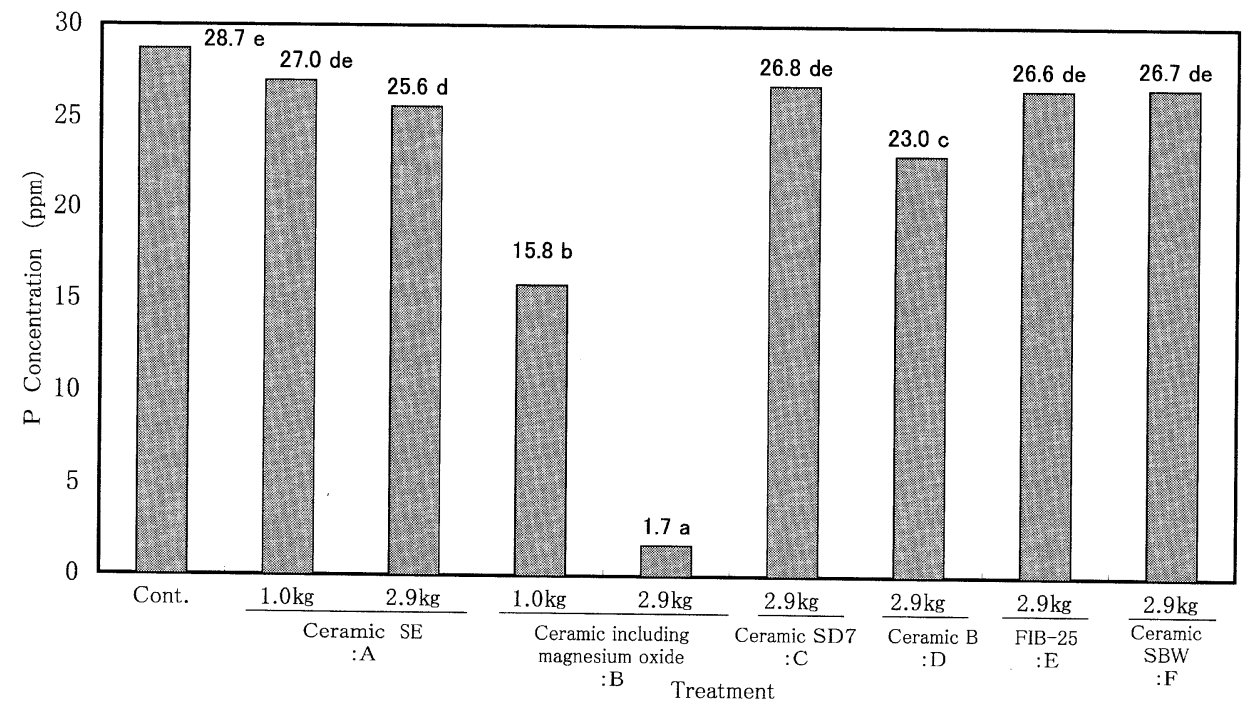

Fig. 3 The effects of ceramics materials addition on the phosphorus concentration in nutrient solution (Exp. 2).

Different letters are significantly different at $\mathrm{p}<0.05$ according to Duncan's new multiple range test.

$\mathrm{pH}$ 值は，B2 区が 8.87 と処理区内で最も高かった (Table 4).

$\mathrm{EC}$ 值は B1，B2 区でそれぞれ 1.281，1.251 と低下 する傾向が認められ，また E区に抢いても 1.280 と無 処理区よりも低下した(Table 4).

B 区に認められたりン酸吸着除去効果は，アンモニア ガス吸着に見られた 従来のカキガラ主体の手法9) との詳細な比較検討が望ま れる. 養液中のリン酸濃度の減少はセラミックスに混和 した酸化マグネシウムと養液中のリン酸が化学結合しリ ン酸マグネシウム, $\mathrm{MgHPO}_{4} ・ 3 \mathrm{H}_{2} \mathrm{O}$ あるいは $\mathrm{MgH}_{4}$
$\left(\mathrm{PO}_{4}\right)_{2} \cdot 5 \mathrm{H}_{2} \mathrm{O}$ としてセラミックス内に取り込まれたも のと思われた．今後酸化マグネシウムの混和率と気孔率 を高めればなお一層の効果が期待できる.

一方, 藻の発生は一般に窒素を主とした養分の存在が 大きく作用し, EC 值が高いと発生が甚だしくなる. 実 際 $\mathrm{EC}$ の低下が認められ，ある程度アンモニアの吸着除 去がなされたと思われた $\mathrm{B}$ 区と $\mathrm{E}$ 区では吸光度の低下 が著しく, 藻の発生が抑制された。無処理とあまり差異 が認められなかった他の資材処理区でも, 藻の発生の抑 制は認められたので，気孔率の変化の作用とともに，他 の要因の関与も考慮する必要がある。セラミックス資材 
に含有されている各種成分の溶出とセラミックスへの成 分吸着が深く関与しているとも思われ，これらの関係を 明らかにするために，リン酸濃度のみでなく，他の成分 についての検討も必要と思われた。

なお $\mathrm{pH}$ と水質の関与は明膫ではなかった。

以上より, 養液への酸化マグネシウム入りセラミック スの添加は, リン酸吸着による水質浄化と藻の発生抑制 に著しい効果を示した. 今後他の手法との比較の中 で1 9), さらにより効能を高めるために, 酸化マグネシ ウムの混和率と気孔率, また水量に応じた添加量, さら に効果の持続性についてのさらなる検討が必要と思われ た。またリン酸含量の減少と藻の発生との関係は明瞭で ない場合も見られたので，今後の検討が必要である。

\section{摘 要}

セラミックス資材による水質浄化について検討した。 いずれのセラミックス資材の添加も藻の発生を抑制した。 特に酸化マグネシウム入りセラミックスと FIB-25 での 抑制効果が高かった。

$\mathrm{pH}$ は酸化マグネシウム入りセラミックス処理区で高 くなった.

$\mathrm{EC}$ は酸化マグネシウム入りセラミックスと FIB-25 区で低下する傾向が認められた。

酸化マグネシウム入りセラミックスの添加は, 藻の発 生抑制とリン酸吸着による水質浄化に著しい効果を示し た.

同資材の今後の利用開発が期待される.

\section{謝辞}

本研究を遂行するに当たり，宇治電化学工業(株)には
資材の提供や多くのアドバイスをいただいた，ここに謝 意を表します。

\section{引用文献}

1）日本水質污濁研究協会編：湖沼環境調査指針，公 害対策技術同友会, pp. 129-134(1982)

2）福元康文, 坪内正行, 西村安代, 島崎一彦: 脱水 へドロの植栽土及び農地培土としての再利用に関 する研究，園学雑，68(別 2)：132(1999)

3）福元康文, 坪内正行, 西村安代, 島崎一彦: 製紙 スラッジの植栽培土としての再利用に関する研究, 園学雑, 69(別 1)：123(2000)

4）福元康文, 坪内正行, 西村安代, 島崎一彦: 浚渫 污泥の植栽培土としての再利用に関する研究, (第 3 報) 製紙スラッジの土壌還元型育苗ポットと しての再利用, 園学雑, 69(別 2) : 164 (2000)

5）松本 聡：ウキクサによる富栄養塩吸収とその利 用，化学と生物，19：594-600 (1981)

6）宮崎 彰，徳田眞二，縣 和一，窪田文武，宋 祥甫：水上栽培したシロガヤツリ (Cyperus alter nifolius L.) の光合成生産と水質浄化能力につい て，日作記，66(2)：325-326(1997)

7）宮崎 彰, 窪田文武, 縣 和一, 宋 祥甫：水上 栽培したイネとシロガヤツリの水質浄化効果の比 較，日作記，68(4)：570-575(1999)

8）嶋田典司，矢島 聡，渡邊幸雄：オオサンショ ウモによる水質浄化に関する研究(1)オオサン ショウモによる $\mathrm{N}, \mathrm{P}$ 吸収の基礎的実験, 千葉 大園学報, 41(4)：15-21(1988)

9）加藤俊博，飯田孝則，大濃正直，安田公昭：脱窒 菌及びカキ殼を利用したトマトロックウール栽培 廃液の浄化技術, 園学雑, 70 (別 1)：272(2001)

10) Ueda H. and Hamayoshi M.: Sepiolite as a deodorant material : an ESR study of its properties, J. Mat. Sci., 27 : 4997-5002(1992) 